Review

\title{
STAT3 signaling in ovarian cancer: a potential therapeutic target
}

\author{
Renba Liang, Xishan Chen, Li Chen, Fangzhu Wan, Kaihua Chen, Yongchu Sun, Xiaodong Zhu ${ }^{凶}$ \\ Department of Radiation Oncology, Guangxi Medical University Cancer Hospital and Cancer Institute of Guangxi Zhuang Autonomous Region, Nanning, \\ Guangxi, P.R. China \\ $\triangle$ Corresponding author: Xiaodong Zhu, Address: Department of Radiation Oncology, Guangxi Medical University Cancer Hospital, No. 71 He Di Road, \\ Nanning 530021, Guangxi, China. Tel.: +86-13978873616; E-mail: zhuxdonggxmu@126.com \\ (0) The author(s). This is an open access article distributed under the terms of the Creative Commons Attribution License (https://creativecommons.org/licenses/by/4.0/). \\ See http://ivyspring.com/terms for full terms and conditions.
}

Received: 2019.03.18; Accepted: 2019.09.08; Published: 2020.01.01

\begin{abstract}
Accumulating evidence has shown that Signal Transducer and Activator of Transcription 3 (STAT3) is thought to be a promising target for cancer therapy as STAT3 is frequently overexpressed in a wide range of cancer cells as well as clinical specimens, promoting tumor progression. It is widely accepted that STAT3 regulates a variety of cellular processes, such as tumor cell growth, survival, invasion, cancer stem cell-like characteristic, angiogenesis and drug-resistance. In this review, we focus on the role of STAT3 in tumorigenesis in ovarian cancer and discuss the existing inhibitors of STAT3 signaling that can be promisingly developed as the strategies for ovarian cancer therapy.
\end{abstract}

Key words: STAT3, ovarian cancer, tumorigenesis, inhibitors

\section{Introduction}

Signal Transducer and Activator of Transcription 3 (STAT3) is a member of STAT family proteins which includes STAT1, STAT2, STAT3, STAT4, STAT5A, STAT5B, and STAT6 ${ }^{1}$. Studies have identified that STAT3 consists of several distinct domains: the N-terminal domain crucial for dimer-dimer interaction, the coiled-coil containing protein interaction domain, the DNA binding domain (DBD), the linker domain, the Src-homology 2(SH2) domain binding to related receptors, the domain containing tyrosine residue at position 705 (Tyr-705), and the C-terminal domain necessary for transcriptional activation-4(Figure 1). In general, STAT3 emerges as an inactive state located in the cytoplasm. STAT3 is activated through phosphorylation of Tyr-705 by binding to the cytoplasmic part of receptor tyrosine kinases including EGFR 5,6 , or by receptor associated kinases including JAK (Janus kinase), or non-receptor kinases including Src, or diverse stimulation ${ }^{4}$, 7-9. Activated STAT3 forms homodimers or heterodimers through reciprocal pTyr-SH2 interaction, then translocate into nucleus and bind to special elements of STAT3-targeted genes (Figure 2), subsequently resulting in the transcription of these genes, such as Bcl2, c-myc, cyclinD1, survivin, MMP2 and MMP910-14. Ultimately, these genes exhibit their biofunction promoting tumorigenesis and progression.

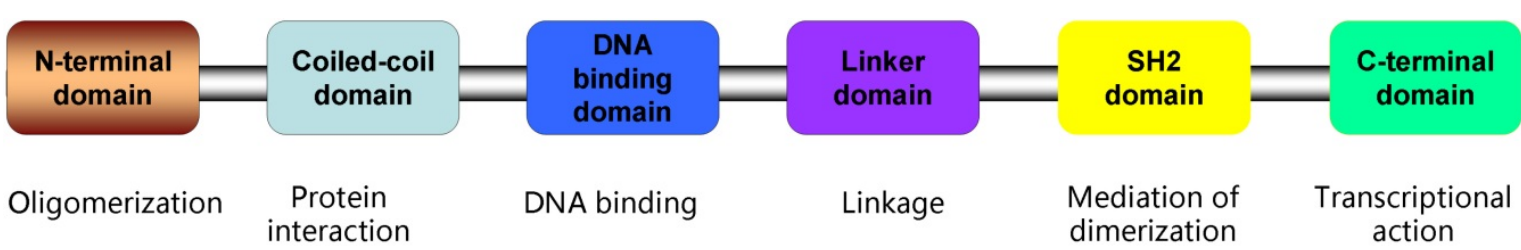

Figure 1. Linear topology of STAT3 structure. As shown, STAT3 is made up of the N-terminal domain, the coiled-coil domain, the DNA binding domain (DBD), the linker domain, the Src-homology 2(SH2) domain, and the C-terminal domain. The tyrosine residue at position 705 (Tyr-705) is close to SH2 domain. 
Ovarian cancer is one of the most lethal gynecological malignancies among women. According to the origin of tissue, ovarian tumor can be classified into distinct types, including epithelium cell tumor, stromal endocrine cell tumor, and germ cell tumor. Moreover, epithelial ovarian cancer (EOC), as a heterogeneous disease and accounting for over $90 \%$ of primary ovarian tumors, can also be divided into several different subtypes, such as serous, clear cell, mucinous, endometrioid, transitional cell, mixed, and undifferentiated type ${ }^{15}$. Unfortunately, ovarian cancer has frequently reached advanced stage when patients are at the time of diagnosis ${ }^{16,17}$. Therefore, it is of great importance to identify the signaling pathway involved in tumorigenesis and progression of ovarian cancer.

Interestingly, a significant body of evidence has highlighted the importance of STAT3 signaling, which is aberrantly activated in ovarian cancer cell lines and tissue samples detecting by microarray analysis, real-time reverse transcription-PCR, western blot as well as luciferase reporter, and associated with ovarian tumor development ${ }^{3},{ }^{18-21}$. The STAT3 signaling is critical for ovarian cancer progression, such as promoting cell proliferation, survival, invasion, stem cell-like characteristic, angiogenesis and chemo-resistance (Figure 3). Conversely, inhibition of STAT3 activation results in the dramatic suppression of tumor growth, suggesting that STAT3 signaling is a promising target for ovarian cancer

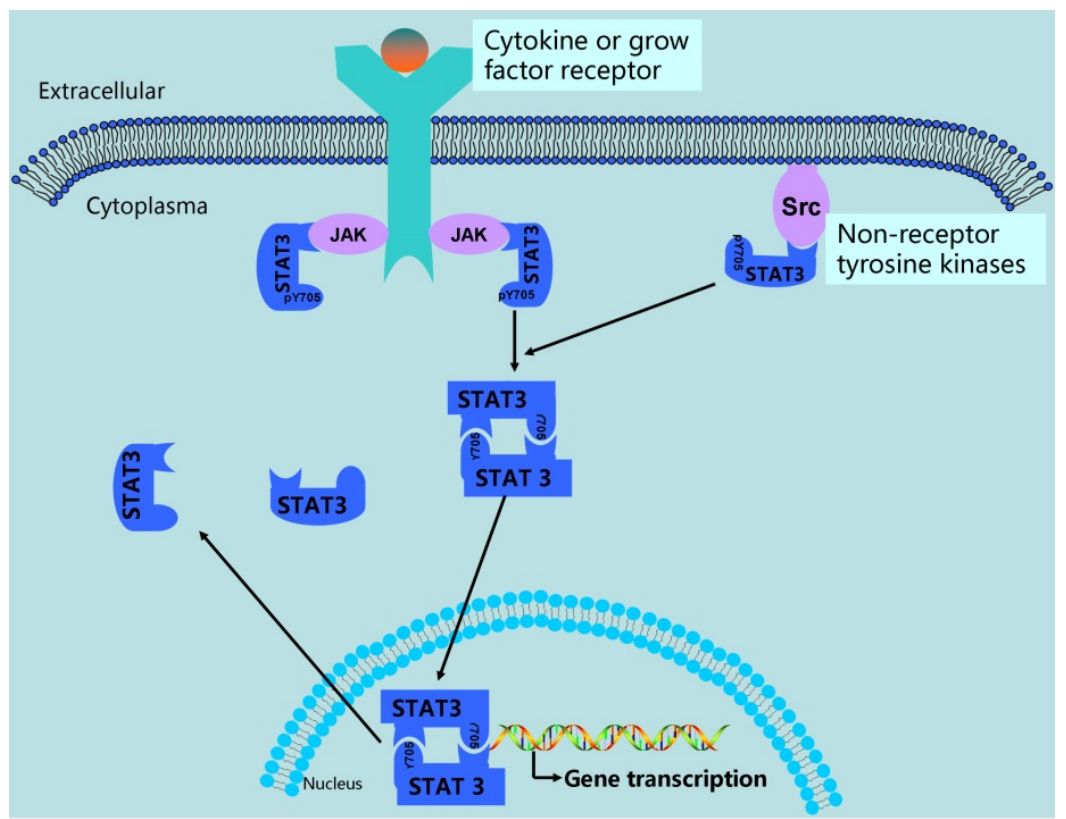

Figure 2. The abnormal activation of STAT3 signaling in ovarian cancer. In ovarian cancer, STAT3 is activated via phosphorylation of Tyr-705 by growth factor receptor tyrosine kinases, cytokine receptor associated kinases (JAK), and non-receptor kinases (Src). After activation, STAT3 forms dimerization and translocate into nucleus, in which they bind to promoter of STAT3-targeted genes, resulting in gene transcription. therapy ${ }^{22-25}$. Thus, it is crucial to have a full understanding of functions of STAT3 in ovarian cancer in order to develop effective therapeutic interventions for ovarian cancer.

In this review, we focus on the role of STAT3 in tumorigenesis of ovarian cancer and summarize the existing agents targeting STAT3 signaling that can be potentially developed as the strategies for ovarian cancer treatment.

\section{Role of STAT3 in tumorigenesis in ovarian cancer}

Studies demonstrates that STAT3 signaling be involved in cell proliferation, survival, invasion, stem cell-like characteristic, angiogenesis and chemoresistance in ovarian cancer:

\section{Migration and invasiveness}

Invasion and metastasis are one of the most important characteristics of malignant tumors. Increasing number of evidence has demonstrated that STAT3 is frequently activated in ovarian carcinoma specimens, especially in high-grade type, and plays a crucial role in the migration and invasiveness of human ovarian cancer19, 26. Moreover, activated STAT3 is found located in focal adhesions known to be conducive to the motility of cell, and depletion of STAT3 decreased invasiveness of ovarian cancer cells $^{19}$. Matrix metalloproteinase 9 (MMP9), a member of matrix metalloproteinase (MMP) family, has been widely reported to engage in the degradation of extracellular matrix, resulting in tumor invasion ${ }^{27}$. Interestingly, a recent study suggests that STAT3 is positively associated with expression of MMP9 in epithelial ovarian cancer. Activated STAT3 directly bind to special element of MMP9 gene promoter, inducing the increasing expression of MMP9. In addition, knockout of STAT3 decreased the expression of MMP-9 at mRNA and protein levels, which suggested that pSTAT3 may get involved in invasiveness and metastasis of ovarian cancer ${ }^{28}$. Likewise, alpinetin, a kind of natural flavonoid, inhibits cell migration through down-regulation of MMP-2 and MMP-9 via suppression of STAT3 signaling in ovarian cancer ${ }^{29}$. Moreover, Seo and co-workers suggest that BLT2, a leukotriene $\mathrm{B}(4)$ receptor, activates STAT3 and concomitantly gives rise to the overexpression of MMP2, leading to mobility of OVCAR-3 and SKOV-3 ovarian cancer cells ${ }^{13}$. 


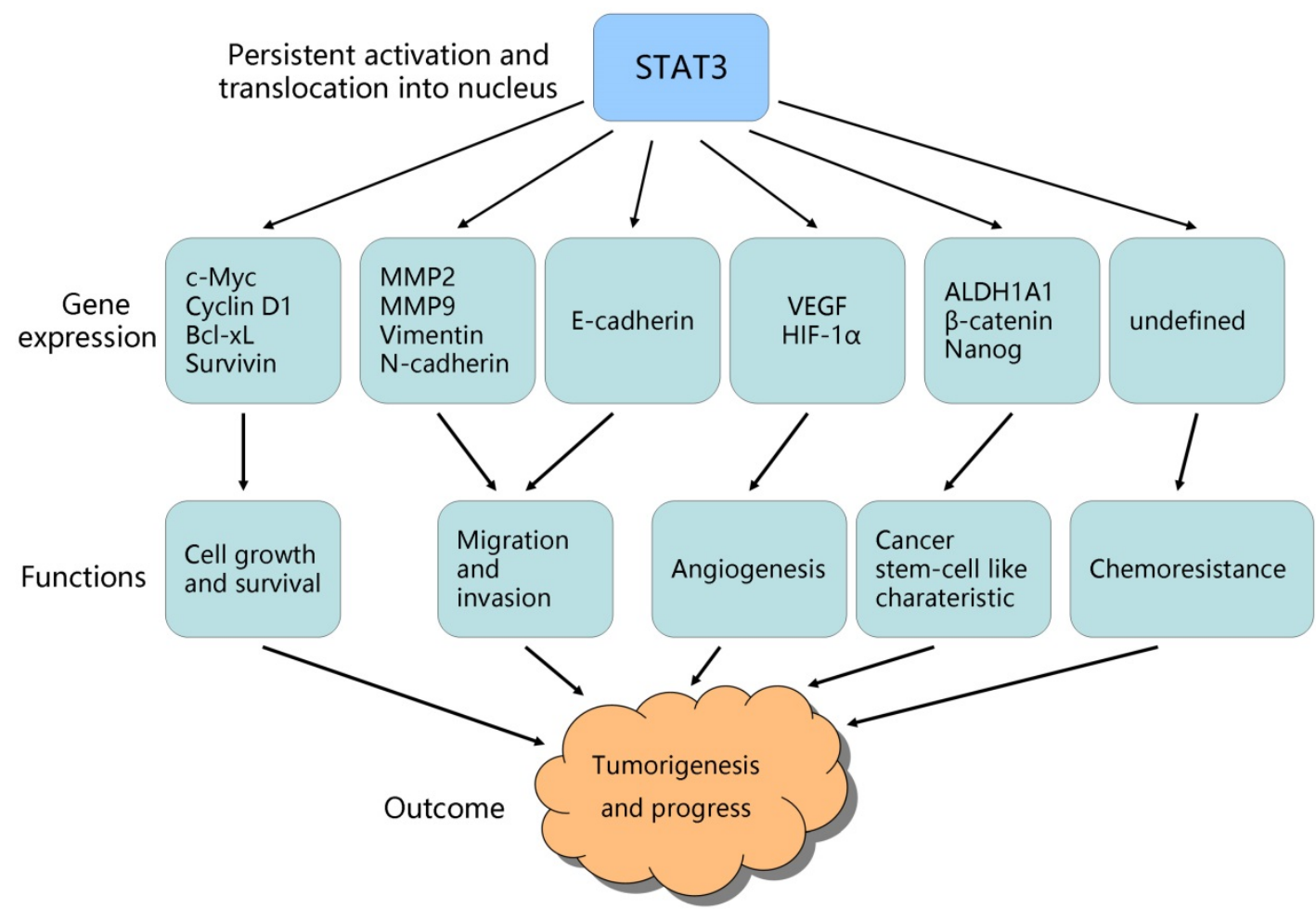

Figure 3. STAT3-targeted genes and their role in tumorigenesis/progress. Persistent activation of STAT3 promotes its-regulated genes expression, which contribute to ovarian cancer growth, survival, invasion, angiogenesis, stem cell-like characteristic, and chemo-resistance.

Epithelial-mesenchymal transition (EMT), which is marked by the downregulation of epithelial markers, such as E-cadherin, together with over-expression of mesenchymal markers, such as $\mathrm{N}$-cadherin, Vimentin and snail, frequently occurs during the process of invasion and migration in tumor ${ }^{30,31}$. It is reported that constitutively activated STAT3 is involved in EMT of ovarian cancer, as evidenced by the upregulation of Vimentin in STAT3-active cells ${ }^{32}$. In addition, investigations in the last decade have identified that epidermal growth factor (EGF) and its receptor (EGFR) as well as IL-6, which frequently upregulated in ovarian cancer, are crucial mediators of EMT $31,33,34$. Activated EGFR increases the level of $\mathrm{N}$-cadherin and Vimentin, in line with activation of STAT3 and IL-6 production. Stimulating ovarian cancer cells with IL-6 promotes STAT3 phosphorylation and cell migration. Moreover, selectively blocking STAT3 signaling brings about the loss of Vimentin, N-cadherin, IL-6 as well as cell movement ${ }^{26,32}$.

\section{Growth and survival}

The crucial role of STAT3 in facilitating tumor cell growth and survival has been well-established ${ }^{35-39}$. At the molecular level, events at quite an early stage have indicated that constitutive activation of STAT3 has a strongly correlation with high levels of Bcl-xL, cyclin D1 and c-myc ${ }^{20,40}$. STAT3 knockdown with specific small interfering RNA causes a loss of cell growth and induces apoptosis in human ovarian cancer cells, consistent with down-regulation of cyclin D1 and survivin level ${ }^{41}$. In addition, support for these finding further is provided by the evidence that treating human ovarian cancer with STAT3 inhibitor HO-3867, a novel compound which decreases the level of Tyrosine-phosphorylated STAT3 (pSTAT3) and then followed by a decline of cyclin D1, survivin and Bcl-2 as well as an ascent of cleaved PARP, caspase- 3 and caspase-7, gives rise to suppression of cell proliferation and survival ${ }^{42-44}$. Similarly, SD-1029 or SD-1008, a small molecule against JAK, induces apoptosis of ovarian cancer cells by cut-down of $\mathrm{Bcl}-\mathrm{X}(\mathrm{L})$ and survivin expression through inhibition of STAT3 phosphorylation ${ }^{45,46}$.

\section{Angiogenesis}

It has been proved that angiogenesis, a process pivotal for nutrition supply for tumor growth and metastasis, is a common phenomenon in malignant disease ${ }^{47}$. Vascular endothelial growth factor (VEGF) and hypoxia-inducible factor-1a (HIF-1a) are two key molecules in promoting angiogenesis ${ }^{48-51}$. It is interesting to note that STAT3 regulates VEGF expression, directly binding to the VEGF promoter and strengthening expression of VEGF and tumor angiogenesis ${ }^{52-54}$. Blocking STAT3 signaling with STAT3 decoy inhibits VEGF expression and decreases 
tumor volumes ${ }^{52,55}$. Furthermore, comparing with non-carcinoma tissues, primary ovarian epithelial carcinoma samples have higher level of pSTAT3 and VEGF56. Likewise, a study has found that IL6-STAT3-HIF signaling is abnormally upregulated in ovarian clear cell cancer samples and patients with such disease achieve clinical responses when administrated with sunitinib, a angiogenesis inhibitor ${ }^{57}$. Beside primary ovarian cancer sample, STAT3 is also activated in ascites-derived ovarian cancer cells (ADOCCs) ${ }^{58}$. HO-3867 deeply inhibits vessel formation and tumor growth in orthotopic mouse model through antagonizing STAT358. In addition, it is commonly accepted that cancer stem cells (CSCs) possess property of tumorigenesis including involving in angiogenesis ${ }^{59}$. Similar to this knowledge, a recent study suggests ovarian cancer stem-like cells (CSLCs) are capable of differentiating into endothelial cells (ECs) and forming microtube network in the presence of chemokine CCL5. Notably, CCL5 signaling activates the NF-kB and STAT3 signal pathways, then facilitating tumor angiogenesis ${ }^{60}$. HIF-1a is another key modulator of angiogenesis ${ }^{61}$. Importantly, STAT3 plays a vital role in regulating HIF-1a expression ${ }^{54,62}$. The same results are also found in ovarian cancer cells. Treating six ovarian cancer cell lines with diindolylmethane decreases activity of cell invasion and angiogenesis through downregulating expression of HIF-1a and VEGF via targeting STAT3 ${ }^{39}$.

\section{Cancer stem cell-like characteristic}

Cancer stem cells (CSCs), similar to normal stem cells (SCs), have the potential of self-renewal and differentiation. Studies more than a decade ago have suggested that CSCs exist in ovarian cancer63, and are believed to participate in chemoresistance, recurrence and angiogenesis ${ }^{63}$. Interestingly, activation of STAT3 is involved in a CSC-like residual population of ovarian cancer cell after treatment with paclitaxel. Inhibiting JAK2/STAT3 pathway brings about restraint of CSC-like characteristics in paclitaxeltreated residual cells in vitro and a rapid decline of tumor burden in vivo as expected ${ }^{23}$. Spheroids, known as aggregates of some malignant cells, are abundant in ovarian CSCs identified by high level of ALDH1A1 and $\beta$-catenin, which are widely considered as CSC markers ${ }^{67}$. Moreover, recent studies have demonstrated that STAT3 correlates with spheroid formation ${ }^{24}$, and c-myc, previously reported to be modulated by STAT320, 40, is found increasing in ovarian cancer spheroids ${ }^{68}, 69$. In addition, CD24 (another CSC marker) positive ovarian cancer cells promote spheroid formation and improve tumorinitiating capacity, accompanied by increased level of
pSTAT3 and STAT3 target genes, also known as stem cell genes Nanog and c-myc ${ }^{70}$, further suggesting that STAT3 has a tight relationship with CSCs or CSC-like phenotypes ${ }^{71,72}$.

\section{Induction of chemotherapy resistance}

Ovarian cancer is one of leading causes of death of patients with gynecologic cancer. Systematic chemotherapy after the cytoreductive surgery is identified standard treatment of advanced ovarian cancer. Although initial response to chemotherapy agents, especially platinum and taxane, is high, most cases unfortunately become chemoresistance, resulting in disease recurrence ultimately ${ }^{15}$. Therefore, a great number of studies are designed to understand the underlying mechanisms by which ovarian cancer develops resistance to chemotherapeutic agents.

Emerging evidence has suggested that pSTAT3 is highly expressed in paclitaxel- and cisplatinresistant ovarian cancer cells ${ }^{21}, 32,73,74$. Inhibition of STAT3 activity reverses chemoresistance and enhances chemotherapeutic drugs-induced apoptosis, accompanied by decreased level of pro-survival genes $\mathrm{Bcl}-\mathrm{xL}, \mathrm{Bcl}-2$ and survivin $21,73,75-78$. These results are in parallel with the findings that it increases toxicity of cisplatin or paclitaxel to ovarian cancer when treated with JAK2 or STAT3 inhibitor, such as AG49079, 80, WP1066 ${ }^{79}$, 80, Diindolylmethane ${ }^{39}$, SD-102945, and SD-100846. Moreover, a recent study reveals that STAT3 polymorphisms may function as an independent marker predicting a poor response to chemotherapy for patients with advanced serous EOC 82 .

Recently, investigations demonstrate that tumor microenvironment, being make up of tumor cells, mesenchymal cells and different kinds of cytokines, is involved in chemoresistance in cancer cells ${ }^{83}$. Carcinoma-associated fibroblasts (CAFs), known to increase chemoresistance in tumor cells ${ }^{84-86}$, are the key components of mesenchymal cells in tumor microenvironment. Importantly, CAFs protect ovarian cancer cells from cisplatin cytotoxicity through activating STAT3 signaling ${ }^{76,87}$. In addition, CAFs secret abundant IL-6. Strengthening EMT via IL-6/JAK2/STAT3 pathway results in paclitaxel resistance in ovarian cancer ${ }^{8}$.

\section{Inhibitor of STAT3 signaling in ovarian cancer}

As discussed above, abnormal activated STAT3 plays a crucial role in tumor properties such as migration, invasiveness, proliferation, survival, angiogenesis, cancer stem cell-like characteristic, and chemoresistance in ovarian cancer, driving it to act as a promising therapeutic target to manage this kind 
disease. To date, a lot of approaches have been carried out around inhibiting STAT3 signaling, such as using small molecules from natural sources, synthetic agents and anti-sense oligonucleotide. Here, we will provide an outlook into natural (Figure 4) and synthetic (Table 1) inhibitors of STAT3 signaling that have been shown to be effective in ovarian cancer management.

Table 1. Synthetic inhibitors targeting STAT3 directly or indirectly in ovarian cancer.

\begin{tabular}{lll}
\hline Agent & Target & References \\
\hline HO-3867 & DNA-binding domain & $42-44,58,135-137$ \\
HO-4200 & DNA-binding domain & 138 \\
H-4318 & DNA-binding domain & 138 \\
LC28 & DNA-binding domain & 140 \\
STAT3 ODN & DNA-binding domain & 143 \\
Stattic & SH2 domain & 73 \\
AG490 & JAK2 & 150 \\
Momelotinib(CYT387) & JAK2 & 151 \\
Ruxolitinib & JAK2 & 71 \\
AZD1480 & JAK2 & 153 \\
WP1066 & JAK2 & 154 \\
SD-1029 & JAK2 & 45 \\
MLS-2384 & JAK/Src & 155 \\
Erlotinib & EGFR & 160 \\
Cetuximab & EGFR & 161 \\
Gefitinib & EGFR & 162 \\
Lapatinib & EGFR & 163 \\
Dasatinib & Src & 167,168 \\
Saratinib & Src & 169 \\
Siltuximab & IL-6 & 174,175 \\
Tocilizumab & IL-6R & 176,177 \\
SC144 & gp130 & 178 \\
siRNA-PLGA/CSO & STAT3 & 179 \\
Oncolytic adenovirus (M4) & STAT3 & 181 \\
\hline
\end{tabular}

\section{Natural STAT3 inhibitors in ovarian cancer}

Standard chemotherapy is indispensable part of ovarian cancer treatment. Despite high sensitivity to chemotherapy, most of patients ultimately become chemoresistance. Moreover, chemotherapy drugs not only have potential to kill cancerous cells, but also generate severe toxic side effects on normal tissues and cells. These side effects limit clinical high dose use, prolong total treatment time, or even results in treatment interruption, which has a negative impact on patient's prognosis. Hence, researchers are working hard to find low-toxic and highly effective anti-tumor drugs, and natural products are an obvious example. Natural compounds are the basis of drug discovery and design, and most of anticancer drugs originate from natural products ${ }^{89}$. Under the efforts of researchers, to date, several natural compounds against STAT3 signaling are explored in preclinical trial or clinical trial in ovarian cancer.

\section{Resveratrol}

Resveratrol, a natural compound with antioxidant and anti-inflammatory function, is derived from red grapes and berries and has drew people's great attention. Resveratrol is thought to be preventive agent of cardiovascular disease ${ }^{90}$. There is also growing evidence that resveratrol possesses anti-tumor potential in a great number of cancers, including ovarian cancer ${ }^{91-96}$. Zhong et al found that resveratrol inhibits cell proliferation and enhances apoptosis of ovarian cancer, and activated STAT3 is the molecule target of resveratrol ${ }^{37}$. Similar to this finding, a recent study suggests that resveratrol suppresses growth, increases apoptosis as well as autophagic activity in ovarian cancer cells, presumably through blocking STAT3 signaling pathway ${ }^{97}$. In addition, IL-6, a pro-inflammatory cytokine which are able to activate STAT3 ${ }^{26}$, promotes cell invasion and metastasis, accompanied by autophagy formation and down-regulation of ARHI (A Ras homologue member I), an imprinted tumor-suppressor gene known to suppress cell growth and motility. On the contrary, resveratrol neutralizes the effect of IL-6 on ovarian cancer cells and reduces level of STAT3 expression ${ }^{95}$. Furthermore, a latest report has demonstrated that ARHI is upregulated, in paralleled with decreased of STAT3 in ovarian cancer cells treated with resveratrol ${ }^{98}$. Altogether, preclinical practices show that resveratrol elicits antitumor effect on ovarian cancer cells. However, there is no clinical trial to assess resveratrol's property in patients with ovarian cancer. Additionally, despite phase I study conducted in patients with colorectal cancer and in healthy volunteers finds resveratrol consumed $5.0 \mathrm{~g}$ daily 14 days is safe and well tolerated ${ }^{99-101}$, it still warrants further clinical investigations to evaluate its clinical activity.<smiles>[R6]Oc1cc(O)cc(/C=C/c2ccc(O)cc2)c1</smiles><smiles>COc1cc(/C=C/C(=O)CC(=O)/C=C/c2ccc(O)c(OC)c2)ccc1O</smiles>

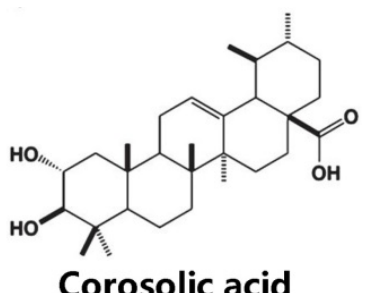

Figure 4. Chemical structures of natural inhibitors of STAT3 in ovarian cancer. 


\section{Curcumin}

Curcumin (diferuloylmethane) is a phenolic component extracted from turmeric (Curcuma longa) and is often used as food additive spice. Intriguingly, modern studies have found that curcumin have more functions other than dietary spice, such as anti-inflammatory and anti-cancer effect ${ }^{102-105}$. Curcumin is involved in inhibition of transformation, survival, and metastasis in cancer ${ }^{106}$. For example, treating ovarian cancer cells with curcumin suppresses activation of STAT3, resulting in decreased cell viability ${ }^{38}$. Moreover, targeting STAT3 phosphorylation by which curcumin inhibits invasion and metastasis of ovarian cancer cells ${ }^{107}$. Apart from the STAT3 pathway, curcumin also inhibits characteristics of ovarian cancer via blocking the other signaling, including sarco/endoplasmic reticulum calcium ATPase, PI3K/ Akt and nuclear factor-kappaB pathway 108-110. Aside from its functions, it is a surprising finding that curcumin is very safe even at a high dose of oral $12 \mathrm{~g}$ per day in human'111-113. Unfortunately, one main drawback to limit its use in medical application is rapid metabolism and low bioavailability ${ }^{114}$. As a consequence, many approaches have been adopted to circumvent this problem, including engineering its analogs by modulating curcumin structure ${ }^{115}$ and improving its delivery systems through loading in nanoparticles ${ }^{116}$. Take HO-3867 for example. HO-3867, a curcumin analog, exhibits substantially higher anticancer efficacy than the parent curcumin ${ }^{117}$. In all, improving its bioavailability, curcumin may be a great potential candidate as an anti-tumor drug in ovarian cancer.

\section{Corosolic acid}

Corosolic acid, a natural triterpenoid compound derived from banaba leaves and apples, has been shown to have anti-tumor effects on a variety of tumor models, such as glioblastoma ${ }^{118}$, prostate cancer $^{119,}{ }^{120}$, retinoblastoma ${ }^{121}$, renal carcinoma ${ }^{122}$, gastric cancer ${ }^{123}$, breast cancer ${ }^{124}$, liver cancer ${ }^{125,}{ }^{126}$, colon cancer ${ }^{127}$, lung adenocarcinoma ${ }^{128}$, cervix adenocarcinoma $^{129}$, osteosarcoma ${ }^{130},{ }^{131}$. Similar to curcumin and resveratrol, CA is a potent STAT3 inhibitor, suppressing cell growth of ovarian cancer and glioblastoma by abrogating STAT3 activity 118,132 . Moreover, since aberrantly activated STAT3 is strongly associated with chemoresistance as mentioned above, CA also enhances cytotoxicity of chemotherapeutic drugs to ovarian cancer cells via inhibition of STAT3 activation ${ }^{132}$. Additionally, tumor microenvironment, as discussed previously, participates in progress of tumor ${ }^{83}$ and tumorassociated macrophages (TAMs) of M2 phenotype is a component of tumor microenvironment. Recent research indicates M2 macrophages regulate cell growth and metastasis of ovarian cancer ${ }^{133}, 134$, and STAT3 is activated in ovarian cancer cells when coculturing with M2 macrophages ${ }^{134}$. Interestingly, CA reduces STAT3 activity in ovarian cancer cells through inhibiting M2 polarization of macrophages ${ }^{132}$. Although the studies of CA in ovarian cancer is relatively rare comparing to curcumin and resveratrol, effects of CA have been well established in certain cancer models, providing rational evidence for conducting further investigations on it and developing it as an inhibitor in ovarian cancer.

\section{Synthetic blockers of STAT3 signaling in ovarian cancer}

As discussed above, because of rapid metabolism or delivery systems, some natural compounds have low bioavailability in serum. Hence, it is necessary to design corresponding analogues or synthesize other novel small molecules that can inhibit STAT3 activation. Besides, given that STAT3 is made up of distinct domains and activated by receptor tyrosine kinases, or receptor associated kinases, or non-receptor kinases, or diverse cytokines, synthetic agents targeting STAT3 signaling are mainly classified into the following categories in ovarian cancer: 1) direct inhibitors targeting the domains of STAT3; 2) indirect inhibitors targeting the upstream factors.

\section{Direct inhibitors of STAT3}

By targeting the DNA-binding domain, $\mathrm{N}$-terminal domain, SH2 domain of STAT3, direct inhibitors interfere with STAT3 activation, resulting in the blockage amplification of STAT3 signaling cascade reaction and concomitantly the decrease of STAT3-regulated gene level.

Therefore, specific domains of STAT3, in theory, are promising targets for designing STAT3 inhibitors. So far, there are some direct inhibitors which interact with the DNA-binding domain in preclinical trial of ovarian cancer. For example, HO-3867, one of diarylidenylpiperidone(DAP)-based synthetic compounds, also known as curcumin analog, directly binds to the STAT3 DNA-binding domain and exclusively inhibits activation of STAT3 without interfering with that of other member of STATs ${ }^{135}$. HO-3867 decreases migration of human ovarian cancer cells. Furthermore, compared with non-transformed cells and tissues, HO-3867 exerts more toxicity, including increasing apoptosis and inhibiting tumor growth, on both in vitro and in vivo using xenograft model ${ }^{135}$. These findings are strongly supported by the results of several reports $42-44,58,136,137$. Similar to HO-3867, HO-4200 and H-4318 are two derivatives of DAP 
compounds that selectively interact with DNAbinding domain of STAT3. Treating cisplatin-resistant ovarian cancer cells with HO-4200 and H-4318 decreases the level of STAT3 target proteins: c-myc, $\mathrm{Bcl}-2, \mathrm{Bcl}-\mathrm{xl}$, survivin and cyclin D1/D2, giving rise to inhibition of cell survival and induction of apoptosis. In addition, HO-4200 and $\mathrm{H}-4318$ also inhibit VEGF expression and decrease migration/invasion activity ${ }^{138}$.

Besides DAP compounds, LC28, designed on the basis of pharmacophore of a STAT3 inhibitor inS3-54139, is another new inhibitor targeting the DNA-binding domain of STAT3140. Huang and co-workers have identified that LC28 significantly inhibits growth of cisplatin-resistant ovarian cancer cells by blocking interaction between STAT3 and DNA $^{140}$. Beside the inhibitors mentioned above, STAT3 decoy oligodeoxynucleotides (ODN) is another strategy inhibiting DNA binding activity of STAT3 ${ }^{141}$. The STAT3 decoy is a double-stranded oligonucleotide binding to STAT3 with a high specificity, and it exhibits anti-proliferation capacity on head and neck cancers as a phase 0 clinical trial shows ${ }^{142}$. Furthermore, in addition to head and neck cancers, an investigation conducted by Zhang et al has revealed that STAT3 decoy ODNs also induces cell apoptosis in xenograft mode of ovarian cancer ${ }^{143}$.

The SH2 domain of STAT3 is extremely important not only for recognition of related receptors, but also for dimerization of STAT3 itself or with other members of STAT family. Then STAT3 is phosphorylated and activated, subsequently translocate into nucleus to realize its biological function. Hence, the $\mathrm{SH} 2$ domain provides us an attractive opportunity for designing specific STAT3 inhibitors. Compared with inhibitors targeting DBD, the number of agents that inactivate $\mathrm{SH} 2$ domain is quite few in ovarian cancer. However, investigators still do all they can do to design new inhibitors directly acting on the SH2 domain. Stattic is an obvious example. Schust et al have suggested that Stattic, a nonpeptidic small molecule, directly inhibits the SH2 domain of STAT3, leading to inactivation of STAT3 and apoptosis of STAT3-dependent cancer cells $^{144}$. More interestingly, as abnormally activated STAT3 plays a critical role in chemoresistance mentioned above, stattic improves the sensitivity of chemo-resistant ovarian cancer cell to cisplatin both in vitro and in vivo ${ }^{73}$.

Apart from DBD and SH2 domain, the N-terminal domain is a vital component of STAT3. The N-terminal domain, also called oligomerization domain, has eight helices mediating tetramerization of two STATs dimers and interaction with other proteins ${ }^{145}$. The forming complex may influence transcriptional activity of STAT3, indicating that the $\mathrm{N}$-terminal domain of STAT3 regulates transcription of STAT3 targeted genes which are involved in tumor progress ${ }^{146}$. Therefore, agents targeting the $\mathrm{N}$-terminal domain may potentially show anticancer efficacy. ST3-H2A2, a highly selective inhibitor of the $\mathrm{N}$-terminal domain of STAT3, suppresses STAT3 signaling ${ }^{147}$. ST3-H2A2 induces expression of proapoptotic genes in cancer cells (PC3, DU145 prostate cancer cells and MCF-7, MDA-MB-231 breast cancer cells), but not in normal epithelial cells (prostate epithelial cells RWPE-1 and human mammary epithelial cells (HMEC)), resulting in apoptotic death of cancer cells ${ }^{147}$. Unfortunately, to date, there is no inhibitors of the N-terminal domain reported in the ovarian cancer.

\section{Indirect inhibitors of STAT3}

STAT3 signaling pathway is a cascade amplification reaction activated by either upstream kinases or diverse cytokines, such as JAK, EGFR, Src as well as IL-6. As a result, these upstream factors are attractive strategies to disturb the activation of STAT3 and there are existing several inhibitors targeting them after long years ongoing efforts. AG490 is an inhibitor of JAK2148. Studies have suggested that AG490 exerts anti-tumor effects on several cancers, including acute lymphoblastic leukaemia ${ }^{148}$, head and neck squamous cell carcinoma ${ }^{149}$, ovarian cancer ${ }^{150}$ and so on. Moreover, AG490 reverses paclitaxel resistance through decreasing the level of pSTAT3 and multidrug resistance protein 1 in ovarian cancer cells ${ }^{150}$. However, there is no clinical trial of AG490 in malignancies in spite of its anti-tumor efficacy in the preclinical studies. Momelotinib and ruxolitinib both are JAK inhibitors and they have been well proved to suppress ovarian cancer growth ${ }^{71,151}$. Despite the fact that ruxolitinib is used in clinical practice in myelofibrosis and momelotinib treatment was noninferior to ruxolitinib for spleen response in Janus kinase inhibitor-naïve patients with myelofibrosis reported by a phase III randomized trial ${ }^{152}$, there is no clinical trial conducted in ovarian cancer. Hence, this may be next step of our work. Except for AG490, Momelotinib and ruxolitinib, there are other existing JAK inhibitors, such as AZD1480153, WP1066154, SD-102945, and MLS-2384155 also having anti-tumor property in ovarian cancer model. It is of particular note here that although AZD1480 confers anti-tumor effects on ovarian cancer in preclinical research, few further studies have been performed in clinical. The possible reason for this phenomenon may be the severe side effect on nervous system when treating myelofibrosis with AZD1480 as a phase I clinical trial reported ${ }^{156}$. 
Beside JAK inhibitors, the EGFR inhibitor is another way to inactivate STAT3 indirectly. Preclinical evidence reveals that EGFR inhibitors, such as Erlotinib, Cetuximab, Gefitinib and lapatinib, decrease the expression of STAT3 ${ }^{157-160}$. Nevertheless, such inhibitors have minimal clinical activity or do not improve progression-free or overall survival in the treatment of patients with ovarian cancer ${ }^{161-164}$. One possible reason for this phenomenon may be the feedback activation of STAT3 signaling pathway in the long run ${ }^{165}$.

Src is a cell membrane-associated non-receptor tyrosine kinase and plays a critical role in proliferation, migration, and differentiation of tumor cells $^{166}$. At the molecular level, activation of Src results in initiating of STAT3 pathway ${ }^{167}$. Therefore, Src is also served as an attractive therapeutic target for cancer management. In fact, a Phase II trial conducted by The Gynecologic Oncology Group has demonstrated that dasatinib, an oral Src inhibitor, shows limited efficacy in patients with recurrent epithelial ovarian cancer when administered alone ${ }^{168}$. However, A recent study suggests that the combination of dasatinib with paclitaxel generates synergistic inhibition in growth of ovarian granulosa cell tumor cells ${ }^{169}$. Interestingly, the finding of saracatinib (another Src inhibitor) is contrary to that of dasatinib as saracatinib does not improve efficacy of weekly paclitaxel in platinum-resistant ovarian cancer ${ }^{170}$.

IL-6 is one of the cytokines and binds specifically to its receptor (IL-6R) to form IL-6/IL-6R complex, then recruits downstream molecular gp130 and ultimately develops as a trimer IL-6/IL-6R/GP130 complex ${ }^{171}$. This trimer gives rise to activation of STAT3 ${ }^{172}$. The IL-6/gp130/STAT3 signaling is frequently activated in tumors and it may be developed as a target for cancer treatment and prevention $^{173}$, 174. Guo et al have reported that siltuximab, a monoclonal anti-IL-6 antibody, significantly inhibits IL-6-induced STAT3 activation and decreases the expression of STAT3 targeted gene in ovarian cancer cells. Moreover, siltuximab restores sensitivity to paclitaxel in paclitaxel-resistant ovarian cancer cell line in vitro. However, combination siltuximab with paclitaxel has limited effect on xenograft mouse mode in vivo ${ }^{175}$. Similarly, there is no clinical benefit from siltuximab monotherapy in patients with advanced/refractory ovarian cancer ${ }^{176}$. Tocilizumab is a humanized IL-6R antibody. Treating clear cell carcinoma of the ovary with tocilizumab impairs the activity of cell invasion and improves sensitivity to chemotherapy ${ }^{177}$. To date, a phase I clinical trial of tocilizumab is finished, finding that it is feasible and safe in EOC patients combined 8 $\mathrm{mg} / \mathrm{kg}$ tocilizumab with doxorubicin or carboplatin ${ }^{178}$. SC144, a first-in-class orally active gp130 inhibitor, shows cytotoxicity including induction of apoptosis and cell death in ovarian cancer cells but no in normal kidney epithelial cells and endometrial epithelial cells. Furthermore, SC144 inhibits tumor growth of xenografts in mouse without substantial toxicity to normal tissues ${ }^{179}$.

At last, using RNA interference (RNAi) technology is another approach to block STAT3 signaling and such strategy has also been adopted in ovarian cancer cells ${ }^{180}$. Despite the efficacy of siRNA in cancer treatment, siRNA has not been widely used in clinical because of its instability and unsatisfactory delivery systems ${ }^{181}$. Hence, researchers have worked on numerous methods for overcome these carriers. Recently, an oncolytic adenovirus (M4), which selectively silences STAT3 expression by producing antisense STAT3 complementary DNA, greatly suppresses survival of ovarian cancer cells but sparing normal cells. In addition, M4 enhances cisplatin antitumor property in vitro and in vivo, and does not exert synergistic toxicity to liver when combined with cisplatin ${ }^{181}$. These findings provide a rationale reason for $\mathrm{M} 4$ further research to develop as an antitumor agent in patients with ovarian cancer.

\section{Conclusions}

Ovarian cancer is one of leading cause of death among women. Conventional chemotherapy is a part of standard treatment in ovarian cancer. However, chemotherapy is poorly tolerated for patients as a result of severe adverse side effects and most of patients are on the road to chemoresistance. Therefore, it is urgent need to design alternative and complementary therapeutic strategies for circumventing this dilemma. Abnormally activated STAT3 has frequently been found in ovarian cancer cells and clinical specimens. Persistent activation of STAT3 enhances cell proliferation, survival, invasion, cancer stem cell-like characteristic, angiogenesis and drug-resistance in ovarian cancer. Hence, STAT3 provides us an attractive target for ovarian cancer treatment and prevention. To date, there are several natural and synthetic inhibitors targeting STAT3 signaling directly or indirectly. Some inhibitors show significant toxicity or have synergistic effects when combined with conventional chemotherapy both in vitro and in vivo but no or little, if any, on normal cells and tissues. However, in spite of great efficacy on cell lines, quite few inhibitors exhibit minimal activity in xenografts or in patients, possibly because of low bioavailability, bad delivery systems and complex environment in vivo. Researchers have adopted numerous ways to address these concerns. In all, 
given the vital role of STAT3 in progress of ovarian cancer and the published reports on STAT3 inhibitors, it is our belief that strategy targeting STAT3 signaling will achieve a great success in clinic of ovarian cancer.

\section{Acknowledgments}

This work was supported by National Natural Science Foundation of China (81760544).

\section{Competing Interests}

The authors have declared that no competing interest exists.

\section{References}

1. Ihle JN. The Stat family in cytokine signaling. Curr Opin Cell Biol 2001;13:211-7.

2. Darnell JJ. STATs and gene regulation. Science 1997;277:1630-5.

3. $\mathrm{Yu} \mathrm{H}$, Jove R. The STATs of cancer--new molecular targets come of age. Nat Rev Cancer 2004;4:97-105.

4. Xiong A, Yang Z, Shen Y, Zhou J, Shen Q. Transcription factor STAT3 as a novel molecular target for cancer prevention. Cancers (Basel) 2014;6:926-57.

5. Fan QW, Cheng CK, Gustafson WC, Charron E, Zipper P, Wong RA, Chen J, Lau J, Knobbe-Thomsen C, Weller M, Jura N, Reifenberger G, et al. EGFR phosphorylates tumor-derived EGFRvIII driving STAT3/5 and progression in glioblastoma. Cancer Cell 2013;24:438-49.

6. Sang Y, Li Y, Song L, Alvarez AA, Zhang W, Lv D, Tang J, Liu F, Chang Z, Hatakeyama S, Hu B, Cheng SY, et al. TRIM59 Promotes Gliomagenesis by Inhibiting TC45 Dephosphorylation of STAT3. Cancer Res 2018;78:1792-804.

7. Darnell JJ, Kerr IM, Stark GR. Jak-STAT pathways and transcriptional activation in response to IFNs and other extracellular signaling proteins. Science 1994:264:1415-21.

8. Siveen KS, Sikka S, Surana R, Dai X, Zhang J, Kumar AP, Tan BK, Sethi G, Bishayee A. Targeting the STAT3 signaling pathway in cancer: role of synthetic and natural inhibitors. Biochim Biophys Acta 2014;1845:136-54.

9. Mohan CD, Bharathkumar H, Bulusu KC, Pandey V, Rangappa S, Fuchs JE, Shanmugam MK, Dai X, Li F, Deivasigamani A, Hui KM, Kumar AP, et al. Development of a novel azaspirane that targets the Janus kinase-signal transducer and activator of transcription (STAT) pathway in hepatocellular carcinoma in vitro and in vivo. J Biol Chem 2014;289:34296-307.

10. Vinkemeier U. Getting the message across, STAT! Design principles of a molecular signaling circuit. J Cell Biol 2004;167:197-201.

11. Gorlich D. Transport into and out of the cell nucleus. EMBO J 1998;17:2721-7.

12. Frank DA. STAT3 as a central mediator of neoplastic cellular transformation. Cancer Lett 2007;251:199-210.

13. Seo JM, Park S, Kim JH. Leukotriene B4 receptor-2 promotes invasiveness and metastasis of ovarian cancer cells through signal transducer and activator of transcription 3 (STAT3)-dependent up-regulation of matrix metalloproteinase 2. I Biol Chem 2012;287:13840-9.

14. Ma J, Zhang T, Novotny-Diermayr V, Tan AL, Cao X. A novel sequence in the coiled-coil domain of Stat3 essential for its nuclear translocation. J Biol Chem 2003;278:29252-60.

15. Jelovac D, Armstrong DK. Recent progress in the diagnosis and treatment of ovarian cancer. CA Cancer J Clin 2011;61:183-203.

16. Cannistra SA. Cancer of the ovary. N Engl J Med 2004;351:2519-29.

17. Vaughan S, Coward JI, Bast RJ, Berchuck A, Berek JS, Brenton JD, Coukos G, Crum CC, Drapkin R, Etemadmoghadam D, Friedlander M, Gabra H, et al. Rethinking ovarian cancer: recommendations for improving outcomes. Nat Rev Cancer 2011;11:719-25.

18. Miklossy G, Hilliard TS, Turkson J. Therapeutic modulators of STAT signalling for human diseases. Nat Rev Drug Discov 2013;12:611-29.

19. Silver DL, Naora H, Liu J, Cheng W, Montell DJ. Activated signal transducer and activator of transcription (STAT) 3: localization in focal adhesions and function in ovarian cancer cell motility. Cancer Res 2004;64:3550-8.

20. Huang M, Page C, Reynolds RK, Lin J. Constitutive activation of stat 3 oncogene product in human ovarian carcinoma cells. Gynecol Oncol 2000;79:67-73.

21. Duan Z, Foster R, Bell DA, Mahoney J, Wolak K, Vaidya A, Hampel C, Lee H, Seiden MV. Signal transducers and activators of transcription 3 pathway activation in drug-resistant ovarian cancer. Clin Cancer Res 2006;12:5055-63.

22. Wen W, Liang W, Wu J, Kowolik CM, Buettner R, Scuto A, Hsieh MY, Hong $\mathrm{H}$, Brown CE, Forman SJ, Horne D, Morgan R, et al. Targeting JAK1/STAT3 signaling suppresses tumor progression and metastasis in a peritoneal model of human ovarian cancer. Mol Cancer Ther 2014;13:3037-48.

23. Abubaker K, Luwor RB, Zhu H, McNally O, Quinn MA, Burns CJ, Thompson EW, Findlay JK, Ahmed N. Inhibition of the JAK2/STAT3 pathway in ovarian cancer results in the loss of cancer stem cell-like characteristics and a reduced tumor burden. BMC Cancer 2014;14:317.
24. Chen MW, Yang ST, Chien MH, Hua KT, Wu CJ, Hsiao SM, Lin H, Hsiao M, $\mathrm{Su}$ JL, Wei LH. The STAT3-miRNA-92-Wnt Signaling Pathway Regulates Spheroid Formation and Malignant Progression in Ovarian Cancer. Cancer Res 2017;77:1955-67.

25. Scheitz CJ, Lee TS, McDermitt DJ, Tumbar T. Defining a tissue stem cell-driven Runx1/Stat3 signalling axis in epithelial cancer. EMBO J 2012;31:4124-39.

26. Colomiere M, Ward AC, Riley C, Trenerry MK, Cameron-Smith D, Findlay J, Ackland L, Ahmed N. Cross talk of signals between EGFR and IL-6R through JAK2/STAT3 mediate epithelial-mesenchymal transition in ovarian carcinomas. Br J Cancer 2009;100:134-44.

27. Vandooren J, Van den Steen PE, Opdenakker G. Biochemistry and molecular biology of gelatinase B or matrix metalloproteinase-9 (MMP-9): the next decade. Crit Rev Biochem Mol Biol 2013;48:222-72.

28. Jia ZH, Jia Y, Guo FJ, Chen J, Zhang XW, Cui MH. Phosphorylation of STAT3 at Tyr705 regulates MMP-9 production in epithelial ovarian cancer. PLoS One 2017;12:e183622.

29. Zhao X, Guo X, Shen J, Hua D. Alpinetin inhibits proliferation and migration of ovarian cancer cells via suppression of STAT3 signaling. Mol Med Rep 2018;18:4030-6

30. Thiery JP. Epithelial-mesenchymal transitions in tumour progression. Nat Rev Cancer 2002;2:442-54

31. Ahmed N, Thompson EW, Quinn MA. Epithelial-mesenchymal interconversions in normal ovarian surface epithelium and ovarian carcinomas: an exception to the norm. J Cell Physiol 2007;213:581-8.

32. Yue P, Zhang X, Paladino D, Sengupta B, Ahmad S, Holloway RW, Ingersoll SB, Turkson J. Hyperactive EGF receptor, Jaks and Stat3 signaling promote enhanced colony-forming ability, motility and migration of cisplatin-resistant ovarian cancer cells. Oncogene 2012;31:2309-22.

33. Psyrri A, Kassar M, Yu Z, Bamias A, Weinberger PM, Markakis S, Kowalski D, Camp RL, Rimm DL, Dimopoulos MA. Effect of epidermal growth factor receptor expression level on survival in patients with epithelial ovarian cancer. Clin Cancer Res 2005;11:8637-43.

34. Lim R, Ahmed N, Borregaard N, Riley C, Wafai R, Thompson EW, Quinn MA, Rice GE. Neutrophil gelatinase-associated lipocalin (NGAL) an early-screening biomarker for ovarian cancer: NGAL is associated with epidermal growth factor-induced epithelio-mesenchymal transition. Int $J$ Cancer 2007; 120:2426-34.

35. Chen L, Wang J, Wu J, Zheng $\mathrm{O}$, Hu J. Indirubin suppresses ovarian cancer cell viabilities through the STAT3 signaling pathway. Drug Des Devel Ther 2018;12:3335-42.

36. Chaluvally-Raghavan P, Jeong KJ, Pradeep S, Silva AM, Yu S, Liu W, Moss T, Rodriguez-Aguayo C, Zhang D, Ram P, Liu J, Lu Y, et al. Direct Upregulation of STAT3 by MicroRNA-551b-3p Deregulates Growth and Metastasis of Ovarian Cancer. Cell Rep 2016;15:1493-504.

37. Zhong LX, Li H, Wu ML, Liu XY, Zhong MJ, Chen XY, Liu J, Zhang Y. Inhibition of STAT3 signaling as critical molecular event in resveratrol-suppressed ovarian cancer cells. J Ovarian Res 2015;8:25.

38. Saydmohammed M, Joseph D, Syed V. Curcumin suppresses constitutive activation of STAT-3 by up-regulating protein inhibitor of activated STAT-3 (PIAS-3) in ovarian and endometrial cancer cells. J Cell Biochem 2010;110:447-56.

39. Kandala PK, Srivastava SK. Diindolylmethane suppresses ovarian cancer growth and potentiates the effect of cisplatin in tumor mouse model by targeting signal transducer and activator of transcription 3 (STAT3). BMC Med 2012;10:9.

40. Huang F, Tong X, Fu L, Zhang R. Knockdown of STAT3 by shRNA inhibits the growth of CAOV3 ovarian cancer cell line in vitro and in vivo. Acta Biochim Biophys Sin (Shanghai) 2008;40:519-25.

41. Cai L, Zhang G, Tong X, You Q, An Y, Wang Y, Guo L, Wang T, Zhu D, Zheng J. Growth inhibition of human ovarian cancer cells by blocking STAT3 activation with small interfering RNA. Eur J Obstet Gynecol Reprod Biol 2010;148:73-80.

42. McCann GA, Naidu S, Rath KS, Bid HK, Tierney BJ, Suarez A, Varadharaj S, Zhang J, Hideg K, Houghton P, Kuppusamy P, Cohn DE, et al. Targeting constitutively-activated STAT3 in hypoxic ovarian cancer, using a novel STAT3 inhibitor. Oncoscience 2014:1:216-28.

43. Tierney BJ, McCann GA, Cohn DE, Eisenhauer E, Sudhakar M, Kuppusamy P, Hideg K, Selvendiran K. HO-3867, a STAT3 inhibitor induces apoptosis by inactivation of STAT3 activity in BRCA1-mutated ovarian cancer cells. Cancer Biol Ther 2012;13:766-75.

44. Bixel K, Saini U, Kumar BH, Fowler J, Riley M, Wanner R, Deepa PDK, Rajendran S, Konishi I, Matsumura N, Cohn DE, Selvendiran K. Targeting STAT3 by HO3867 induces apoptosis in ovarian clear cell carcinoma. Int J Cancer 2017;141:1856-66.

45. Duan Z, Bradner JE, Greenberg E, Levine R, Foster R, Mahoney J, Seiden MV. SD-1029 inhibits signal transducer and activator of transcription 3 nuclear translocation. Clin Cancer Res 2006;12:6844-52.

46. Duan Z, Bradner J, Greenberg E, Mazitschek R, Foster R, Mahoney J, Seiden MV 8-benzyl-4-oxo-8-azabicyclo[3.2.1]oct-2-ene-6,7-dicarboxylic acid (SD-1008), a novel janus kinase 2 inhibitor, increases chemotherapy sensitivity in human ovarian cancer cells. Mol Pharmacol 2007;72:1137-45.

47. Folkman J. Seminars in Medicine of the Beth Israel Hospital, Boston. Clinical applications of research on angiogenesis. N Engl J Med 1995;333:1757-63. 
48. Grunstein J, Roberts WG, Mathieu-Costello O, Hanahan D, Johnson RS, Tumor-derived expression of vascular endothelial growth factor is a critical factor in tumor expansion and vascular function. Cancer Res 1999;59:1592-8.

49. Shweiki D, Itin A, Soffer D, Keshet E. Vascular endothelial growth factor induced by hypoxia may mediate hypoxia-initiated angiogenesis. Nature 1992;359:843-5.

50. Plate KH, Breier G, Weich HA, Risau W. Vascular endothelial growth factor is a potential tumour angiogenesis factor in human gliomas in vivo. Nature 1992;359:845-8.

51. Semenza GL. Targeting HIF-1 for cancer therapy. Nat Rev Cancer 2003;3:721-32.

52. Niu G, Wright KL, Huang M, Song L, Haura E, Turkson J, Zhang S, Wang T, Sinibaldi D, Coppola D, Heller R, Ellis LM, et al. Constitutive Stat3 activity up-regulates VEGF expression and tumor angiogenesis. Oncogene 2002;21:2000-8.

53. Wei D, Le X, Zheng L, Wang L, Frey JA, Gao AC, Peng Z, Huang S, Xiong HQ, Abbruzzese JL, Xie K. Stat3 activation regulates the expression of vascular endothelial growth factor and human pancreatic cancer angiogenesis and metastasis. Oncogene 2003;22:319-29.

54. Xu Q, Briggs J, Park S, Niu G, Kortylewski M, Zhang S, Gritsko T, Turkson J, Kay H, Semenza GL, Cheng JQ, Jove R, et al. Targeting Stat3 blocks both HIF-1 and VEGF expression induced by multiple oncogenic growth signaling pathways. Oncogene 2005;24:5552-60.

55. Xi S, Gooding WE, Grandis JR. In vivo antitumor efficacy of STAT3 blockade using a transcription factor decoy approach: implications for cancer therapy. Oncogene 2005;24:970-9.

56. Chen H, Ye D, Xie X, Chen B, Lu W. VEGF, VEGFRs expressions and activated STATs in ovarian epithelial carcinoma. Gynecol Oncol 2004;94:630-5.

57. Anglesio MS, George J, Kulbe H, Friedlander M, Rischin D, Lemech C, Power J, Coward J, Cowin PA, House CM, Chakravarty P, Gorringe KL, et al. IL6-STAT3-HIF signaling and therapeutic response to the angiogenesis inhibitor sunitinib in ovarian clear cell cancer. Clin Cancer Res 2011:17:2538-48.

58. Saini U, Naidu S, ElNaggar AC, Bid HK, Wallbillich JJ, Bixel K, Bolyard C, Suarez AA, Kaur B, Kuppusamy P, Hays J, Goodfellow PJ, et al. Elevated STAT3 expression in ovarian cancer ascites promotes invasion and metastasis: a potential therapeutic target. Oncogene 2017;36:168-81.

59. Yao H, Liu N, Lin MC, Zheng J. Positive feedback loop between cancer stem cells and angiogenesis in hepatocellular carcinoma. Cancer Lett 2016;379:213-9.

60. Tang S, Xiang T, Huang S, Zhou J, Wang Z, Xie R, Long H, Zhu B. Ovarian cancer stem-like cells differentiate into endothelial cells and participate in tumor angiogenesis through autocrine CCL5 signaling. Cancer Lett 2016:376:137-47

61. Ahn GO, Seita J, Hong BJ, Kim YE, Bok S, Lee CJ, Kim KS, Lee JC, Leeper NJ, Cooke JP, Kim HJ, Kim IH, et al. Transcriptional activation of hypoxia-inducible factor-1 (HIF-1) in myeloid cells promotes angiogenesis through VEGF and S100A8. Proc Natl Acad Sci U S A 2014;111:2698-703.

62. Zhang K, Han ES, Dellinger TH, Lu J, Nam S, Anderson RA, Yim JH, Wen W. Cinnamon extract reduces VEGF expression via suppressing HIF-1alpha gene expression and inhibits tumor growth in mice. Mol Carcinog 2017;56:436-46.

63. Bapat SA, Mali AM, Koppikar CB, Kurrey NK. Stem and progenitor-like cells contribute to the aggressive behavior of human epithelial ovarian cancer. Cancer Res 2005;65:3025-9.

64. Ahmed N, Abubaker K, Findlay J, Quinn M. Cancerous ovarian stem cells: obscure targets for therapy but relevant to chemoresistance. J Cell Biochem 2013;114:21-34.

65. Steg AD, Bevis KS, Katre AA, Ziebarth A, Dobbin ZC, Alvarez RD, Zhang K, Conner M, Landen CN. Stem cell pathways contribute to clinical chemoresistance in ovarian cancer. Clin Cancer Res 2012;18:869-81.

66. Markowska A, Sajdak S, Markowska J, Huczynski A. Angiogenesis and cancer stem cells: New perspectives on therapy of ovarian cancer. Eur J Med Chem 2017;142:87-94.

67. Condello S, Morgan CA, Nagdas S, Cao L, Turek J, Hurley TD, Matei D. beta-Catenin-regulated ALDH1A1 is a target in ovarian cancer spheroids. Oncogene 2015;34:2297-308.

68. Lawrenson K, Sproul D, Grun B, Notaridou M, Benjamin E, Jacobs IJ, Dafou D, Sims AH, Gayther SA. Modelling genetic and clinical heterogeneity in epithelial ovarian cancers. Carcinogenesis 2011;32:1540-9.

69. Lawrenson K, Grun B, Benjamin E, Jacobs IJ, Dafou D, Gayther SA. Senescent fibroblasts promote neoplastic transformation of partially transformed ovarian epithelial cells in a three-dimensional model of early stage ovarian cancer. Neoplasia 2010;12:317-25.

70. Burgos-Ojeda D, Wu R, McLean K, Chen YC, Talpaz M, Yoon E, Cho KR, Buckanovich RJ. CD24+ Ovarian Cancer Cells Are Enriched for Cancer-Initiating Cells and Dependent on JAK2 Signaling for Growth and Metastasis. Mol Cancer Ther 2015;14:1717-27.

71. McLean K, Tan L, Bolland DE, Coffman LG, Peterson LF, Talpaz M, Neamati $\mathrm{N}$, Buckanovich RJ. Leukemia inhibitory factor functions in parallel with interleukin-6 to promote ovarian cancer growth. Oncogene 2018.

72. Ning Y, Cui Y, Li X, Cao X, Chen A, Xu C, Cao J, Luo X. Co-culture of ovarian cancer stem-like cells with macrophages induced SKOV3 cells stemness via IL-8/STAT3 signaling. Biomed Pharmacother 2018;103:262-71.

73. Ji T, Gong D, Han Z, Wei X, Yan Y, Ye F, Ding W, Wang J, Xia X, Li F, Hu W, $\mathrm{Lu} \mathrm{Y}$, et al. Abrogation of constitutive Stat3 activity circumvents cisplatin resistant ovarian cancer. Cancer Lett 2013;341:231-9.

74. Park J, Park SY, Kim JH. Leukotriene B4 receptor-2 contributes to chemoresistance of SK-OV-3 ovarian cancer cells through activation of signal transducer and activator of transcription-3-linked cascade. Biochim Biophys Acta 2016;1863:236-43.

75. Han Z, Feng J, Hong Z, Chen L, Li W, Liao S, Wang X, Ji T, Wang S, Ma D, Chen G, Gao Q. Silencing of the STAT3 signaling pathway reverses the inherent and induced chemoresistance of human ovarian cancer cells. Biochem Biophys Res Commun 2013;435:188-94.

76. Yan H, Guo BY, Zhang S. Cancer-associated fibroblasts attenuate Cisplatin-induced apoptosis in ovarian cancer cells by promoting STAT3 signaling. Biochem Biophys Res Commun 2016;470:947-54

77. Duan Z, Ames RY, Ryan M, Hornicek FJ, Mankin H, Seiden MV. CDDO-Me, a synthetic triterpenoid, inhibits expression of IL-6 and Stat3 phosphorylation in multi-drug resistant ovarian cancer cells. Cancer Chemother Pharmacol 2009;63:681-9.

78. Yang Z, Liu Y, Liao J, Gong C, Sun C, Zhou X, Wei X, Zhang T, Gao Q, Ma D, Chen G. Quercetin induces endoplasmic reticulum stress to enhance cDDP cytotoxicity in ovarian cancer: involvement of STAT3 signaling. FEBS J 2015;282:1111-25.

79. Selvendiran K, Bratasz A, Kuppusamy ML, Tazi MF, Rivera BK, Kuppusamy $P$. Hypoxia induces chemoresistance in ovarian cancer cells by activation of signal transducer and activator of transcription 3. Int $J$ Cancer 2009;125:2198-204.

80. Xu Y, Zhang J, Wu J, Zhong S, Li H. Inhibition of JAK2 Reverses Paclitaxel Resistance in Human Ovarian Cancer Cells. Int J Gynecol Cancer 2015;25:1557-64.

81. Tang YJ, Sun ZL, Wu WG, Xing J, He YF, Xin DM, Han P. Inhibitor of signal transducer and activator of transcription 3 (STAT3) suppresses ovarian cancer growth, migration and invasion and enhances the effect of cisplatin in vitro. Genet Mol Res 2015;14:2450-60.

82. Permuth-Wey J, Fulp WJ, Reid BM, Chen Z, Georgeades C, Cheng JQ, Magliocco A, Chen DT, Lancaster JM. STAT3 polymorphisms may predict an unfavorable response to first-line platinum-based therapy for women with advanced serous epithelial ovarian cancer. Int J Cancer 2016;138:612-9.

83. Meads MB, Gatenby RA, Dalton WS. Environment-mediated drug resistance: a major contributor to minimal residual disease. Nat Rev Cancer 2009:9:665-74.

84. Shiga $K$, Hara M, Nagasaki $T$, Sato $T$, Takahashi $H$, Takeyama $H$. Cancer-Associated Fibroblasts: Their Characteristics and Their Roles in Tumor Growth. Cancers (Basel) 2015;7:2443-58.

85. Muerkoster SS, Werbing V, Koch D, Sipos B, Ammerpohl O, Kalthoff H, Tsao MS, Folsch UR, Schafer H. Role of myofibroblasts in innate chemoresistance of pancreatic carcinoma--epigenetic downregulation of caspases. Int J Cancer 2008;123:1751-60.

86. Amornsupak $\mathrm{K}$, Insawang $\mathrm{T}$, Thuwajit $\mathrm{P}, \mathrm{O}-$ Charoenrat $\mathrm{P}$, Eccles $\mathrm{SA}$, Thuwajit C. Cancer-associated fibroblasts induce high mobility group box 1 and contribute to resistance to doxorubicin in breast cancer cells. BMC Cancer 2014;14:955.

87. Zhou B, Sun C, Li N, Shan W, Lu H, Guo L, Guo E, Xia M, Weng D, Meng L, $\mathrm{Hu}$ J, Ma D, et al. Cisplatin-induced CCL5 secretion from CAFs promotes cisplatin-resistance in ovarian cancer via regulation of the STAT3 and PI3K/Akt signaling pathways. Int J Oncol 2016;48:2087-97.

88. Wang L, Zhang F, Cui JY, Chen L, Chen YT, Liu BW. CAFs enhance paclitaxel resistance by inducing EMT through the IL6/JAK2/STAT3 pathway. Oncol Rep 2018;39:2081-90.

89. Banerjee P, Erehman J, Gohlke BO, Wilhelm T, Preissner R, Dunkel M. Super Natural II--a database of natural products. Nucleic Acids Res 2015;43:D935-9.

90. Kopp P. Resveratrol, a phytoestrogen found in red wine. A possible explanation for the conundrum of the 'French paradox'? Eur J Endocrinol 1998;138:619-20

91. Joe AK, Liu H, Suzui M, Vural ME, Xiao D, Weinstein IB. Resveratrol induces growth inhibition, S-phase arrest, apoptosis, and changes in biomarker expression in several human cancer cell lines. Clin Cancer Res 2002;8:893-903.

92. Hsieh TC, Wu JM. Differential effects on growth, cell cycle arrest, and induction of apoptosis by resveratrol in human prostate cancer cell lines. Exp Cell Res 1999;249:109-15.

93. Clement MV, Hirpara JL, Chawdhury SH, Pervaiz S. Chemopreventive agent resveratrol, a natural product derived from grapes, triggers CD95 signaling-dependent apoptosis in human tumor cells. Blood 1998;92:996-1002.

94. Lu R, Serrero G. Resveratrol, a natural product derived from grape, exhibits antiestrogenic activity and inhibits the growth of human breast cancer cells. I Cell Physiol 1999;179:297-304.

95. Ferraresi A, Phadngam S, Morani F, Galetto A, Alabiso O, Chiorino G, Isidoro C. Resveratrol inhibits IL-6-induced ovarian cancer cell migration through epigenetic up-regulation of autophagy. Mol Carcinog 2017;56:1164-81.

96. Tan L, Wang W, He G, Kuick RD, Gossner G, Kueck AS, Wahl H, Opipari AW, Liu JR. Resveratrol inhibits ovarian tumor growth in an in vivo mouse model. Cancer 2016;122:722-9.

97. Zhong LX, Zhang Y, Wu ML, Liu YN, Zhang P, Chen XY, Kong QY, Liu J, Li $\mathrm{H}$. Resveratrol and STAT inhibitor enhance autophagy in ovarian cancer cells. Cell Death Discov 2016;2:15071.

98. Zhong LX, Nie JH, Liu J, Lin LZ. Correlation of ARHI upregulation with growth suppression and STAT3 inactivation in resveratrol-treated ovarian cancer cells. Cancer Biomark 2018;21:787-95

99. Howells LM, Berry DP, Elliott PJ, Jacobson EW, Hoffmann E, Hegarty B, Brown K, Steward WP, Gescher AJ. Phase I randomized, double-blind pilot study of micronized resveratrol (SRT501) in patients with hepatic 
metastases--safety, pharmacokinetics, and pharmacodynamics. Cancer Prev Res (Phila) 2011;4:1419-25.

100. Brown VA, Patel KR, Viskaduraki M, Crowell JA, Perloff $M$, Booth TD, Vasilinin G, Sen A, Schinas AM, Piccirilli G, Brown K, Steward WP, et al. Repeat dose study of the cancer chemopreventive agent resveratrol in healthy volunteers: safety, pharmacokinetics, and effect on the insulin-like growth factor axis. Cancer Res 2010;70:9003-11.

101. Patel KR, Brown VA, Jones DJ, Britton RG, Hemingway D, Miller AS, West KP, Booth TD, Perloff M, Crowell JA, Brenner DE, Steward WP, et al. Clinical pharmacology of resveratrol and its metabolites in colorectal cancer patients. Cancer Res 2010;70:7392-9.

102. Banerjee M, Tripathi LM, Srivastava VM, Puri A, Shukla R. Modulation of inflammatory mediators by ibuprofen and curcumin treatment during chronic inflammation in rat. Immunopharmacol Immunotoxicol 2003;25:213-24.

103. Lantz RC, Chen GJ, Solyom AM, Jolad SD, Timmermann BN. The effect of turmeric extracts on inflammatory mediator production. Phytomedicine 2005;12:445-52.

104. Shanmugam MK, Rane G, Kanchi MM, Arfuso F, Chinnathambi A, Zayed ME, Alharbi SA, Tan BK, Kumar AP, Sethi G. The multifaceted role of curcumin in cancer prevention and treatment. Molecules 2015;20:2728-69.

105. Deguchi A. Curcumin targets in inflammation and cancer. Endocr Metab Immune Disord Drug Targets 2015;15:88-96.

106. Kunnumakkara AB, Anand P, Aggarwal BB. Curcumin inhibits proliferation, invasion, angiogenesis and metastasis of different cancers through interaction with multiple cell signaling proteins. Cancer Lett 2008;269:199-225.

107. Seo JH, Jeong KJ, Oh WJ, Sul HJ, Sohn JS, Kim YK, Cho DY, Kang JK, Park CG, Lee HY. Lysophosphatidic acid induces STAT3 phosphorylation and ovarian cancer cell motility: their inhibition by curcumin. Cancer Lett 2010;288:50-6.

108. Seo JA, Kim B, Dhanasekaran DN, Tsang BK, Song YS. Curcumin induces apoptosis by inhibiting sarco/endoplasmic reticulum Ca2+ ATPase activity in ovarian cancer cells. Cancer Lett 2016;371:30-7.

109. Yu Z, Wan Y, Liu Y, Yang J, Li L, Zhang W. Curcumin induced apoptosis via PI3K/Akt-signalling pathways in SKOV3 cells. Pharm Biol 2016;54:2026-32.

110. Lin YG, Kunnumakkara AB, Nair A, Merritt WM, Han LY, Armaiz-Pena GN, Kamat AA, Spannuth WA, Gershenson DM, Lutgendorf SK, Aggarwal BB, Sood AK. Curcumin inhibits tumor growth and angiogenesis in ovarian carcinoma by targeting the nuclear factor-kappaB pathway. Clin Cancer Res 2007;13:3423-30.

111. Sharma RA, Euden SA, Platton SL, Cooke DN, Shafayat A, Hewitt HR, Marczylo TH, Morgan B, Hemingway D, Plummer SM, Pirmohamed M, Gescher AJ, et al. Phase I clinical trial of oral curcumin: biomarkers of systemic activity and compliance. Clin Cancer Res 2004;10:6847-54.

112. Lao CD, Ruffin MT, Normolle D, Heath DD, Murray SI, Bailey JM, Boggs ME, Crowell J, Rock CL, Brenner DE. Dose escalation of a curcuminoid formulation. BMC Complement Altern Med 2006;6:10.

113. Cheng AL, Hsu CH, Lin JK, Hsu MM, Ho YF, Shen TS, Ko JY, Lin JT, Lin BR, Ming-Shiang W, Yu HS, Jee SH, et al. Phase I clinical trial of curcumin, a chemopreventive agent, in patients with high-risk or pre-malignant lesions. Anticancer Res 2001;21:2895-900.

114. Anand P, Kunnumakkara AB, Newman RA, Aggarwal BB. Bioavailability of curcumin: problems and promises. Mol Pharm 2007;4:807-18

115. Nagaraju GP, Benton L, Bethi SR, Shoji M, El-Rayes BF. Curcumin analogs: Their roles in pancreatic cancer growth and metastasis. Int J Cancer 2018.

116. Saxena V, Hussain MD. Polymeric mixed micelles for delivery of curcumin to multidrug resistant ovarian cancer. I Biomed Nanotechnol 2013;9:1146-54.

117. Dayton A, Selvendiran K, Kuppusamy ML, Rivera BK, Meduru S, Kalai T, Hideg K, Kuppusamy P. Cellular uptake, retention and bioabsorption of HO-3867, a fluorinated curcumin analog with potential antitumor properties. Cancer Biol Ther 2010:10:1027-32.

118. Fujiwara Y, Komohara Y, Ikeda T, Takeya M. Corosolic acid inhibits glioblastoma cell proliferation by suppressing the activation of signal transducer and activator of transcription-3 and nuclear factor-kappa B in tumor cells and tumor-associated macrophages. Cancer Sci 2011;102:206-11.

119. Ma B, Zhang H, Wang Y, Zhao A, Zhu Z, Bao X, Sun Y, Li L, Zhang Q. Corosolic acid, a natural triterpenoid, induces ER stress-dependent apoptosis in human castration resistant prostate cancer cells via activation of IRE-1/JNK, PERK/CHOP and TRIB3. J Exp Clin Cancer Res 2018;37:210.

120. Yang J, Wu R, Li W, Gao L, Yang Y, Li P, Kong AN. The triterpenoid corosolic acid blocks transformation and epigenetically reactivates Nrf2 in TRAMP-C1 prostate cells. Mol Carcinog 2018;57:512-21.

121. Wang K, Zhu X, Yao Y, Yang M, Zhou F, Zhu L. Corosolic acid induces cell cycle arrest and cell apoptosis in human retinoblastoma Y-79 cells via disruption of MELK-FoxM1 signaling. Oncol Rep 2018;39:2777-86.

122. Woo SM, Seo SU, Min KJ, Im SS, Nam JO, Chang JS, Kim S, Park JW, Kwon TK. Corosolic acid induces non-apoptotic cell death through generation of lipid reactive oxygen species production in human renal carcinoma caki cells. Int I Mol Sci 2018;19.

123. Cheng QL, Li HL, Li YC, Liu ZW, Guo XH, Cheng YJ. CRA(Crosolic Acid) isolated from Actinidia valvata Dunn.Radix induces apoptosis of human gastric cancer cell line BGC823 in vitro via down-regulation of the NF-kappaB pathway. Food Chem Toxicol 2017;105:475-85.

124. Wen L, Guo R, You L, Abbasi AM, Li T, Fu X, Liu RH. Major triterpenoids in Chinese hawthorn "Crataegus pinnatifida" and their effects on cell proliferation and apoptosis induction in MDA-MB-231 cancer cells. Food Chem Toxicol 2017;100:149-60.
125. Xu Y, Zhao $Y, X u$ Y, Guan $Y$, Zhang X, Chen $Y$, Wu $Q$, Zhu G, Chen $Y$, Sun F, Wang J, Yu Y. Blocking inhibition to YAP by actinomycind enhances anti-tumor efficacy of corosolic acid in treating liver cancer. Cell Signal 2017;29:209-17.

126. Ku CY, Wang YR, Lin HY, Lu SC, Lin JY. Corosolic acid Inhibits hepatocellular carcinoma cell migration by targeting the VEGFR2/Src/FAK pathway. PLoS One 2015;10:e126725.

127. Kim JH, Kim YH, Song GY, Kim DE, Jeong YJ, Liu KH, Chung YH, Oh S. Ursolic acid and its natural derivative corosolic acid suppress the proliferation of APC-mutated colon cancer cells through promotion of beta-catenin degradation. Food Chem Toxicol 2014;67:87-95

128. Nho KJ, Chun JM, Kim HK. Corosolic acid induces apoptotic cell death in human lung adenocarcinoma A549 cells in vitro. Food Chem Toxicol 2013;56:8-17.

129. Xu Y, Ge R, Du J, Xin H, Yi T, Sheng J, Wang Y, Ling C. Corosolic acid induces apoptosis through mitochondrial pathway and caspase activation in human cervix adenocarcinoma HeLa cells. Cancer Lett 2009;284:229-37.

130. Cai X, Zhang H, Tong D, Tan Z, Han D, Ji F, Hu W. Corosolic acid triggers mitochondria and caspase-dependent apoptotic cell death in osteosarcoma MG-63 cells. Phytother Res 2011;25:1354-61.

131. Horlad H, Fujiwara Y, Takemura K, Ohnishi K, Ikeda T, Tsukamoto H, Mizuta H, Nishimura Y, Takeya M, Komohara Y. Corosolic acid impairs tumor development and lung metastasis by inhibiting the immunosuppressive activity of myeloid-derived suppressor cells. Mol Nutr Food Res 2013;57:1046-54.

132. Fujiwara Y, Takaishi K, Nakao J, Ikeda T, Katabuchi H, Takeya M, Komohara $Y$. Corosolic acid enhances the antitumor effects of chemotherapy on epithelial ovarian cancer by inhibiting signal transducer and activator of transcription 3 signaling. Oncol Lett 2013;6:1619-23.

133. Yin M, Li X, Tan S, Zhou HJ, Ji W, Bellone S, Xu X, Zhang H, Santin AD, Lou G, Min W. Tumor-associated macrophages drive spheroid formation during early transcoelomic metastasis of ovarian cancer. J Clin Invest 2016;126:4157-73.

134. Takaishi K, Komohara Y, Tashiro H, Ohtake H, Nakagawa T, Katabuchi H, Takeya M. Involvement of M2-polarized macrophages in the ascites from advanced epithelial ovarian carcinoma in tumor progression via Stat3 activation. Cancer Sci 2010;101:2128-36.

135. Rath KS, Naidu SK, Lata P, Bid HK, Rivera BK, McCann GA, Tierney BJ, Elnaggar AC, Bravo V, Leone G, Houghton P, Hideg K, et al. HO-3867, a safe STAT3 inhibitor, is selectively cytotoxic to ovarian cancer. Cancer Res 2014;74:2316-27.

136. Selvendiran K, Tong L, Bratasz A, Kuppusamy ML, Ahmed S, Ravi Y, Trigg NJ, Rivera BK, Kalai T, Hideg K, Kuppusamy P. Anticancer efficacy of a difluorodiarylidenyl piperidone (HO-3867) in human ovarian cancer cells and tumor xenografts. Mol Cancer Ther 2010;9:1169-79.

137. Selvendiran $K$, Ahmed S, Dayton A, Ravi $Y$, Kuppusamy ML, Bratasz A Rivera BK, Kalai T, Hideg K, Kuppusamy P. HO-3867, a synthetic compound, inhibits the migration and invasion of ovarian carcinoma cells through downregulation of fatty acid synthase and focal adhesion kinase. Mol Cancer Res 2010;8:1188-97.

138. ElNaggar AC, Saini U, Naidu S, Wanner R, Sudhakar M, Fowler J, Nagane M, Kuppusamy P, Cohn DE, Selvendiran K. Anticancer potential of diarylidenyl piperidone derivatives, HO-4200 and H-4318, in cisplatin resistant primary ovarian cancer. Cancer Biol Ther 2016;17:1107-15.

139. Huang W, Dong Z, Chen Y, Wang F, Wang CJ, Peng H, He Y, Hangoc G, Pollok K, Sandusky G, Fu XY, Broxmeyer HE, et al. Small-molecule inhibitors targeting the DNA-binding domain of STAT3 suppress tumor growth, metastasis and STAT3 target gene expression in vivo. Oncogene 2016;35:783-92.

140. Huang W, Liu Y, Wang J, Yuan X, Jin HW, Zhang LR, Zhang JT, Liu ZM, Cui JR. Small-molecule compounds targeting the STAT3 DNA-binding domain suppress survival of cisplatin-resistant human ovarian cancer cells by inducing apoptosis. Eur J Med Chem 2018;157:887-97.

141. Leong PL, Andrews GA, Johnson DE, Dyer KF, Xi S, Mai JC, Robbins PD, Gadiparthi S, Burke NA, Watkins SF, Grandis JR. Targeted inhibition of Stat3 with a decoy oligonucleotide abrogates head and neck cancer cell growth. Proc Natl Acad Sci U S A 2003;100:4138-43.

142. Sen M, Thomas SM, Kim S, Yeh JI, Ferris RL, Johnson JT, Duvvuri U, Lee J, Sahu N, Joyce S, Freilino ML, Shi H, et al. First-in-human trial of a STAT3 decoy oligonucleotide in head and neck tumors: implications for cancer therapy. Cancer Discov 2012;2:694-705.

143. Zhang X, Liu P, Zhang B, Mao H, Shen L, Ma Y. Inhibitory effects of STAT3 decoy oligodeoxynucleotides on human epithelial ovarian cancer cell growth in vivo. Int J Mol Med 2013;32:623-8.

144. Schust J, Sperl B, Hollis A, Mayer TU, Berg T. Stattic: a small-molecule inhibitor of STAT3 activation and dimerization. Chem Biol 2006;13:1235-42.

145. Becker S, Groner B, Muller CW. Three-dimensional structure of the Stat3beta homodimer bound to DNA. Nature 1998;394:145-51

146. Primiano T, Baig M, Maliyekkel A, Chang BD, Fellars S, Sadhu J, Axenovich SA, Holzmayer TA, Roninson IB. Identification of potential anticancer drug targets through the selection of growth-inhibitory genetic suppressor elements. Cancer Cell 2003:4:41-53.

147. Timofeeva OA, Tarasova NI, Zhang X, Chasovskikh S, Cheema AK, Wang H, Brown ML, Dritschilo A. STAT3 suppresses transcription of proapoptotic genes in cancer cells with the involvement of its N-terminal domain. Proc Natl Acad Sci U S A 2013;110:1267-72. 
148. Meydan N, Grunberger T, Dadi H, Shahar M, Arpaia E, Lapidot Z, Leeder JS, Freedman M, Cohen A, Gazit A, Levitzki A, Roifman CM. Inhibition of acute lymphoblastic leukaemia by a Jak-2 inhibitor. Nature 1996;379:645-8.

149. Liu JF, Deng WW, Chen L, Li YC, Wu L, Ma SR, Zhang WF, Bu LL, Sun ZJ. Inhibition of JAK2/STAT3 reduces tumor-induced angiogenesis and myeloid-derived suppressor cells in head and neck cancer. Mol Carcinog 2018;57:429-39.

150. Xu Y, Zhang J, Wu J, Zhong S, Li H. Inhibition of JAK2 reverses paclitaxel resistance in human ovarian cancer cells. Int J Gynecol Cancer 2015;25:1557-64.

151. Abubaker K, Luwor RB, Escalona R, McNally O, Quinn MA, Thompson EW, Findlay JK, Ahmed N. Targeted Disruption of the JAK2/STAT3 Pathway in Combination with Systemic Administration of Paclitaxel Inhibits the Priming of Ovarian Cancer Stem Cells Leading to a Reduced Tumor Burden. Front Oncol 2014;4:75.

152. Mesa RA, Kiladjian JJ, Catalano JV, Devos T, Egyed M, Hellmann A, McLornan D, Shimoda K, Winton EF, Deng W, Dubowy RL, Maltzman JD, et al. SIMPLIFY-1: a phase III randomized trial of momelotinib versus ruxolitinib in Janus kinase inhibitor-naive patients with myelofibrosis. J Clin Oncol 2017;35:3844-50

153. Gritsina G, Xiao F, O'Brien SW, Gabbasov R, Maglaty MA, Xu RH, Thapa RJ, Zhou Y, Nicolas E, Litwin S, Balachandran S, Sigal LJ, et al. Targeted blockade of JAK/STAT3 signaling inhibits ovarian carcinoma growth. Mol Cancer Ther 2015;14:1035-47.

154. Kim B, Kim HS, Kim S, Haegeman G, Tsang BK, Dhanasekaran DN, Song YS. Adipose stromal cells from visceral and subcutaneous fat facilitate migration of ovarian cancer cells via IL-6/JAK2/STAT3 pathway. Cancer Res Treat 2017;49:338-49.

155. Liu L, Gaboriaud N, Vougogianopoulou K, Tian Y, Wu J, Wen W, Skaltsounis L, Jove R. MLS-2384, a new 6-bromoindirubin derivative with dual JAK/Src kinase inhibitory activity, suppresses growth of diverse cancer cells. Cancer Biol Ther 2014;15:178-84.

156. S V, R H, J M, JC S, R B, P M, W T, J C, H K, V R. A phase I, open-label, multi-center study of the JAK2 inhibitor AZD1480 in patients with myelofibrosis. Leukemia research 2015;39:157-63.

157. Ung N, Putoczki TL, Stylli SS, Ng I, Mariadason JM, Chan TA, Zhu HJ, Luwor RB. Anti-EGFR therapeutic efficacy correlates directly with inhibition of STAT3 activity. Cancer Biol Ther 2014;15:623-32.

158. Xue F, Liu Y, Chu H, Wen Y, Yan L, Tang Q, Xiao E, Zhang D, Zhang H. eIF5A2 is an alternative pathway for cell proliferation in cetuximab-treated epithelial hepatocellular carcinoma. Am J Transl Res 2016;8:4670-81.

159. Bartolowits MD, Brown W, Ali R, Pedley AM, Chen O, Harvey KE, Wendt MK, Davisson VJ. Selective inhibition of STAT3 phosphorylation using a nuclear-targeted kinase inhibitor. ACS Chem Biol 2017;12:2371-8.

160. Shu T, Li Y, Wu X, Li B, Liu Z. Down-regulation of HECTD3 by HER2 inhibition makes serous ovarian cancer cells sensitive to platinum treatment. Cancer Lett 2017;411:65-73.

161. Vergote IB, Jimeno A, Joly F, Katsaros D, Coens C, Despierre E, Marth C, Hall M, Steer CB, Colombo N, Lesoin A, Casado A, et al. Randomized phase III study of erlotinib versus observation in patients with no evidence of disease progression after first-line platin-based chemotherapy for ovarian carcinoma: a European Organisation for Research and Treatment of CancerGynaecological Cancer Group, and Gynecologic Cancer Intergroup study. J Clin Oncol 2014;32:320-6.

162. Schilder RJ, Pathak HB, Lokshin AE, Holloway RW, Alvarez RD, Aghajanian C, Min H, Devarajan K, Ross E, Drescher CW, Godwin AK. Phase II trial of single agent cetuximab in patients with persistent or recurrent epithelial ovarian or primary peritoneal carcinoma with the potential for dose escalation to rash. Gynecol Oncol 2009;113:21-7.

163. Posadas EM, Liel MS, Kwitkowski V, Minasian L, Godwin AK, Hussain MM, Espina V, Wood BJ, Steinberg SM, Kohn EC. A phase II and pharmacodynamic study of gefitinib in patients with refractory or recurrent epithelial ovarian cancer. Cancer 2007;109:1323-30.

164. Garcia AA, Sill MW, Lankes HA, Godwin AK, Mannel RS, Armstrong DK, Carolla RL, Liepman MK, Spirtos NM, Fischer EG, Leslie KK. A phase II evaluation of lapatinib in the treatment of persistent or recurrent epithelial ovarian or primary peritoneal carcinoma: a gynecologic oncology group study. Gynecol Oncol 2012;124:569-74.

165. Wen W, Wu J, Liu L, Tian Y, Buettner R, Hsieh MY, Horne D, Dellinger TH, Han ES, Jove R, Yim JH. Synergistic anti-tumor effect of combined inhibition of EGFR and JAK/STAT3 pathways in human ovarian cancer. Mol Cancer 2015;14:100.

166. Huang $C$, Zhang $Z$, Chen L, Lee HW, Ayrapetov MK, Zhao TC, Hao Y, Gao I, Yang C, Mehta GU, Zhuang Z, Zhang X, et al. Acetylation within the N- and C-terminal domains of Src regulates distinct roles of STAT3-mediated tumorigenesis. Cancer Res 2018;78:2825-38.

167. Song L, Turkson J, Karras JG, Jove R, Haura EB. Activation of Stat3 by receptor tyrosine kinases and cytokines regulates survival in human non-small cell carcinoma cells. Oncogene 2003;22:4150-65.

168. Schilder RJ, Brady WE, Lankes HA, Fiorica JV, Shahin MS, Zhou XC, Mannel RS, Pathak HB, Hu W, Alpaugh RK, Sood AK, Godwin AK. Phase II evaluation of dasatinib in the treatment of recurrent or persistent epithelial ovarian or primary peritoneal carcinoma: a Gynecologic Oncology Group study. Gynecol Oncol 2012;127:70-4.

169. Haltia UM, Andersson N, Yadav B, Farkkila A, Kulesskiy E, Kankainen M, Tang J, Butzow R, Riska A, Leminen A, Heikinheimo M, Kallioniemi O, et al.
Systematic drug sensitivity testing reveals synergistic growth inhibition by dasatinib or mTOR inhibitors with paclitaxel in ovarian granulosa cell tumor cells. Gynecol Oncol 2017;144:621-30.

170. McNeish IA, Ledermann JA, Webber L, James L, Kaye SB, Hall M, Hall G, Clamp A, Earl H, Banerjee S, Kristeleit R, Raja F, et al. A randomised, placebo-controlled trial of weekly paclitaxel and saracatinib (AZD0530) in platinum-resistant ovarian, fallopian tube or primary peritoneal cancerdagger. Ann Oncol 2014;25:1988-95.

171. Murakami M, Hibi M, Nakagawa N, Nakagawa T, Yasukawa K, Yamanishi K, Taga T, Kishimoto T. IL-6-induced homodimerization of gp130 and associated activation of a tyrosine kinase. Science 1993;260:1808-10.

172. Klemm JD, Schreiber SL, Crabtree GR. Dimerization as a regulatory mechanism in signal transduction. Annu Rev Immunol 1998;16:569-92.

173. Garbers C, Aparicio-Siegmund S, Rose-John S. The IL-6/gp130/STAT3 signaling axis: recent advances towards specific inhibition. Curr Opin Immunol 2015;34:75-82

174. Chen X, Tian J, Su GH, Lin J. Blocking IL-6/GP130 signaling inhibits cell viability/proliferation, glycolysis, and colony forming activity in human pancreatic cancer cells. Curr Cancer Drug Targets 2018.

175. Guo Y, Nemeth J, O'Brien C, Susa M, Liu X, Zhang Z, Choy E, Mankin $\mathrm{H}_{\text {, }}$ Hornicek F, Duan Z. Effects of siltuximab on the IL-6-induced signaling pathway in ovarian cancer. Clin Cancer Res 2010;16:5759-69.

176. Angevin E, Tabernero J, Elez E, Cohen SJ, Bahleda R, van Laethem JL, Ottensmeier C, Lopez-Martin JA, Clive S, Joly F, Ray-Coquard I, Dirix L, et al. A phase I/II, multiple-dose, dose-escalation study of siltuximab, an anti-interleukin-6 monoclonal antibody, in patients with advanced solid tumors. Clin Cancer Res 2014;20:2192-204.

177. Yanaihara N, Hirata Y, Yamaguchi N, Noguchi Y, Saito M, Nagata C, Takakura S, Yamada K, Okamoto A. Antitumor effects of interleukin-6 (IL-6)/interleukin-6 receptor (IL-6R) signaling pathway inhibition in clear cell carcinoma of the ovary. Mol Carcinog 2016;55:832-41.

178. Dijkgraaf EM, Santegoets SJ, Reyners AK, Goedemans R, Wouters MC, Kenter GG, van Erkel AR, van Poelgeest MI, Nijman HW, van der Hoeven JJ, Welters $\mathrm{MJ}$, van der Burg SH, et al. A phase I trial combining carboplatin/doxorubicin with tocilizumab, an anti-IL-6R monoclonal antibody, and interferon-alpha2b in patients with recurrent epithelial ovarian cancer. Ann Oncol 2015;26:2141-9.

179. Xu S, Grande F, Garofalo A, Neamati N. Discovery of a novel orally active small-molecule gp130 inhibitor for the treatment of ovarian cancer. Mol Cancer Ther 2013;12:937-49.

180. Zhao Y, Zheng C, Zhang L, Chen Y, Ye Y, Zhao M. Knockdown of STAT3 expression in SKOV3 cells by biodegradable siRNA-PLGA/CSO conjugate micelles. Colloids Surf B Biointerfaces 2015;127:155-63.

181. Whitehead KA, Langer R, Anderson DG. Knocking down barriers: advances in siRNA delivery. Nat Rev Drug Discov 2009;8:129-38.

182. Han Z, Hong Z, Gao Q, Chen C, Hao Z, Ji T, Hu W, Yan Y, Feng J, Liao S, Wu $\mathrm{P}$, Wang D, et al. A potent oncolytic adenovirus selectively blocks the STAT3 signaling pathway and potentiates cisplatin antitumor activity in ovarian cancer. Hum Gene Ther 2012;23:32-45. 